\title{
Research on the Safeguard Mechanism of University- Industry Collaboration in Nuclear Power Industry's Engineering Talents Cultivation
}

\author{
Changda $\mathrm{Du}^{1}$, Baolin Wen ${ }^{1}$ and Hongbo Shi ${ }^{1, *}$ \\ ${ }^{1}$ School of Economics and Management, Harbin Institute of Technology, Weihai, Shandong 264209, China \\ *Corresponding author.Email: shihongbo@hit.edu.cn
}

\begin{abstract}
In the new sci-tech revolution and industrial transformation, the main objective of training engineering talents is to cultivate talents with innovation and expertise to meet the needs of economic and social development. The realization of the goal depends on whether the cooperation between universities and enterprises can create the effective talents cultivation mode. First, this paper constructs the elements of university-industry collaboration safeguard mechanisms including laws, regulations, mechanisms and systems. Meanwhile, a questionnaire was conducted among directors from universities and enterprises in charge of cooperative projects in the nuclear power industry. By analyzing the data, this paper summarizes the current situation and shortcomings of the safeguard mechanism. Finally, countermeasures and suggestions for the construction of the safeguard mechanism are proposed.
\end{abstract}

Keywords: engineering talents cultivation, university-industry collaboration, safeguard mechanism

\section{INTRODUCTION}

Developing environmentally friendly nuclear energy is one of important measures to solve the energy problem. Nuclear power, a kind of clean energy with high utilization rate, develops rapidly in the recent years. Talents are the fundamental condition to innovate nuclear power technology and improve the safety of nuclear power operation. Only through talents' innovation can the nuclear power industry grow sustainably. Nowadays, the nuclear power industry needs engineering talents who not only understand the development of the industry and the direction of technological innovation, but also effectively implement technical research projects. This means higher requirements for the talents cultivation and education mode in the nuclear power industry.

The research purpose of this paper is to promote the establishment of the systematic, scientific and reasonable education mechanism in the current university-industry collaboration, and the results of the study have great significance for the education reform of talents cultivation in the nuclear power industry. Based on the analysis of the current situation and existing problems of universityindustry collaboration safeguard mechanisms for engineering talents in the nuclear power industry, this paper analyzes the elements influencing the construction of university-industry collaboration safeguard mechanisms. Moreover, it illustrates countermeasures and suggestions to the government, universities and enterprises, aiming at improving the current situation of university-industry collaboration.

\section{LITERATURE REVIEW}

\subsection{Several Modes of University-Industry Collaboration in Cultivating Engineering Talents}

University-industry collaboration refers to the cooperation between enterprises and universities in talents cultivation and scientific research. By combining scientific research, technological development, product production and enterprise experts teaching, it effectively improves the practical ability of engineering talents.

The cultivation of engineering talents mainly includes five university-industry collaboration modes: "CDIO", "Order","Industry-university-research cooperation","Inpost internship", "Modularization"."CDIO" places engineering talents cultivation in the production of enterprises, emphasizing the establishment of engineering foundation under the steps of conceiving, designing, implementing and operating real-world products [1]. "Order" refers to the signing of a cooperation agreement between the university and the enterprise to clarify the responsibilities and obligations of both sides. It not only improves the enthusiasm of enterprises to participate in talents cultivation, but also provides support for engineering talents cultivation [2]. "Industry-university-research cooperation" is mainly composed of a four-section cooperation chain, which includes theoretical teaching in universities, practical training in enterprises, joint research between universities and enterprises, production [2]. "In- 
post internship" means that enterprises provide internship positions for students. Under the joint guidance of teachers from universities and enterprises, students complete the same work as employees of enterprises [3]. "Modularization" means that the university-industry collaboration cultivation program is divided into teaching modules to ensure that each module has clear teaching objectives, and it requires universities and enterprises to implement modular teaching according to the different learning stages of students and the relationship between teaching modules [3].

\subsection{The Safeguard Mechanism of University- Industry Collaboration in Cultivating Engineering Talents}

From the perspective of policies and laws, policies of university-industry collaboration such as direct consulting assistance and tax breaks are the core factor to form a scientific and effective cooperation, and the development of university-industry collaboration depends on the improvement of the policies, the perfection of coordination institutions of university-industry collaboration and the clear responsibility of the executive body of policy implementation [4]. Universities and enterprises have different goals and priorities, so the distribution of power and knowledge sharing between universities and enterprises is mainly determined by regulations [5].

From the perspective of systems, the system of universityindustry collaboration is a formal regulatory framework for values, responsibilities and processes, which is of great significance to the realization of the goals of both sides [6]. In addition, the system promotes the operation of university-industry collaboration, and it also resolves the contradictions and conflicts between stakeholders [7].

From the perspective of the government, governments have six functions in university-industry collaboration: administrative legislation, macro management, overall coordination, financial support, reform promotion and supervision. Financial support can reduce the risk of cooperation, which effectively encourage cooperation between universities and enterprises. Moreover, government funds support research projects that can be commercialized also facilitate knowledge transfer [8]. The policies and supervision of university-industry linkages also promote the development of high-tech industries and the improvement of the teaching quality. For example, in order to enhance the interaction such as knowledge transfer, joint research and consulting services, the Ministry of Education coordinated the establishment of the technology transfer centers in universities [9].

\section{THE ELEMENTS OF THE SAFEGUARD MECHANISM OF UNIVERSITY- INDUSTRY COLLABORATION TALENTS CULTIVATION}

\subsection{Laws and Regulations}

Establishing the legal and regulatory safeguard mechanisms of university-industry collaboration should include two aspects. Direct legal and regulatory safeguard include the Education Act, Higher Education Act and local regulations. Indirect legal and regulatory safeguard include the Labor Law and the Administration of Tax Collection, and local regulations.

\subsection{Mechanisms}

The management mechanism refers to the internal connection, function and operation principle of the management system, and it is the core issue that determines whether the management is effective [10]. The management mechanism of university-industry collaboration includes the organization structure, function division, operation form and the realization of functions. Meanwhile, the certification and evaluation mechanism refers to the function of enterprise qualification identification, the formulation of cultivation framework, the supervision of cooperation process and the evaluation of results in the process of managing universityindustry collaboration. The third is the interest-driven mechanism. For enterprises, the benefits of universityindustry collaboration are not only to obtain talents with problem-solving skills, but also to solve problems arising from technology and operation. For universities, the benefits of university-industry collaboration lie in improving teaching facilities, improving education quality and providing better job security for students. Finally, the balance of interest mechanism refers to the coordination of various conflicts through laws, so that the interests of all parties can reach a reasonable optimization state.

\subsection{Systems}

Systems of university-industry collaboration refer to working procedures or code of conduct jointly complied by schools and enterprises. The systems of universities are systems needed for training the modern skilled personnels including university-industry collaboration management methods, management measures for teachers, students training management methods, professional construction management methods and teaching quality testing management methods, which is produced by the market demand in order to adapt to the society. For enterprises, the systems related to higher education mainly covers university-industry collaboration management methods, training funds system, employee continuing education system and vocational training system. The government systems of vocational education include intern labor protection system, intern preferential policy support system, 
university-industry collaboration cost sharing system, quality control system, inspection system, feedback and rectification system, reward and punishment system.

\section{CURRENT SITUATION OF THE TALENTS CULTIVATION SAFEGUARD MECHANISM ON UNIVERSITY- INDUSTRY COLLABORATION IN THE NUCLEAR POWER INDUSTRY}

\subsection{Questionnaire Design and Data Analysis}

In order to accurately understand the current situation of university-industry collaboration safeguard mechanisms for engineering talents in the nuclear power industry, a questionnaire was conducted on universities and enterprises that have university-industry collaboration programs for engineering talents in the nuclear power industry, and the questionnaire was statistically analyzed.

In this survey, 104 questionnaires were distributed to universities, and 100 were recovered, with a recovery rate of $96.2 \%$. Among them, 97 were effective questionnaires, with an effective rate of $97 \%$. Meanwhile, 100 questionnaires were distributed to enterprises and 96 were recovered, with a recovery rate of $96 \%$. Among them, 92 were effective questionnaires, with an effective rate of $95.8 \%$.

Table 1. Reliability Test for Component Element Scale

\begin{tabular}{|c|c|c|c|c|}
\hline $\begin{array}{l}\text { Measurement } \\
\text { dimensions }\end{array}$ & Measurement items & CITC & $\begin{array}{c}\alpha \text { after } \\
\text { deleting the } \\
\text { item }\end{array}$ & $\alpha$ \\
\hline \multirow{3}{*}{$\begin{array}{c}\text { Laws\& } \\
\text { Regulations }\end{array}$} & The local government formulate relevant regulations. & 0.554 & 0.680 & \multirow{3}{*}{0.741} \\
\hline & $\begin{array}{l}\text { The local government formulate relevant financial investment } \\
\text { policies. }\end{array}$ & 0.629 & 0.586 & \\
\hline & The role of the government needs to be improved. & 0.528 & 0.700 & \\
\hline \multirow{6}{*}{ Mechanisms } & Universities establish relevant departments. & 0.401 & 0.817 & \multirow{6}{*}{0.820} \\
\hline & Universities arrange full-time staffs to manage the collaboration. & 0.550 & 0.800 & \\
\hline & Universities examine and evaluate the collaboration. & 0.608 & 0.793 & \\
\hline & Enterprises establish relevant departments. & 0.624 & 0.790 & \\
\hline & Enterprises arrange full-time staffs to manage the collaboration. & 0.534 & 0.802 & \\
\hline & The inspection and evaluation are conducted by enterprises. & 0.504 & 0.806 & \\
\hline \multirow{3}{*}{ Systems } & Enterprises formulate relevant management methods. & 0.623 & 0.583 & \multirow{3}{*}{0.738} \\
\hline & Preferential policies for enterprises. & 0.532 & 0.710 & \\
\hline & Universities formulate management methods for the collaboration. & 0.551 & 0.682 & \\
\hline
\end{tabular}

As can be seen from Table 1, Cronbach's $\alpha$ of the three subscales of laws and regulations, mechanisms and systems are higher than 0.7 , and CITC values of each measurement item also meet the research requirements. Therefore, all the measurement items pass the reliability test.

Table 2. Reliability Test for Influence Factor Scale

\begin{tabular}{|c|c|c|c|c|}
\hline $\begin{array}{l}\text { Measurement } \\
\text { dimensions }\end{array}$ & Measurement items & CITC & $\begin{array}{c}\alpha \text { after } \\
\text { deleting the } \\
\text { item }\end{array}$ & $\alpha$ \\
\hline \multirow{3}{*}{ Openness } & Adequate funds are available to ensure cultivation. & 0.591 & 0.681 & \multirow{3}{*}{0.741} \\
\hline & There is feedback from society, the tech industry and other aspects. & 0.512 & 0.730 & \\
\hline & Qualified talents in the nuclear power industry can be cultivated. & 0.624 & 0.632 & \\
\hline \multirow{3}{*}{$\begin{array}{l}\text { Far from } \\
\text { Equilibrium }\end{array}$} & Enterprises and universities have different training resources. & 0.606 & 0.803 & \multirow{3}{*}{0.834} \\
\hline & Enterprises and universities have different rights and obligations. & 0.635 & 0.784 & \\
\hline & Enterprises and universities have different organizational goals. & 0.626 & 0.792 & \\
\hline \multirow{3}{*}{$\begin{array}{l}\text { Nonlinear } \\
\text { interaction }\end{array}$} & Tailor the teaching method to students' unique situation. & 0.474 & 0.577 & \multirow{3}{*}{0.663} \\
\hline & $\begin{array}{l}\text { Competition exists in the selection of university teachers and } \\
\text { students, as well as in the recruitment of teachers from enterprises. }\end{array}$ & 0.422 & 0.613 & \\
\hline & $\begin{array}{l}\text { There are third parties to facilitate the operation of the } \\
\text { collaboration. }\end{array}$ & 0.512 & 0.547 & \\
\hline Fluctuation & The level of cooperation is constantly improved. & 0.714 & 0.824 & 0.842 \\
\hline
\end{tabular}




\begin{tabular}{|l|l|l|l|l|}
\hline & The cooperation efficiency is continuously improved. & 0.698 & 0.837 & \\
\cline { 2 - 5 } & The cooperation model is becoming more standardized. & 0.763 & 0.803 & \\
\hline
\end{tabular}

From Table 2, Cronbach's $\alpha$ of each subscale is higher than 0.6 , and CITC values of each measurement item also meet the research requirements. Consequently, it can be considered that all the measurement items pass the reliability test.

\subsection{Current Situation of the Safeguard Mechanism on University-Industry Collaboration}

\subsubsection{Current situation of laws and regulations on university-industry collaboration}

In the investigation of whether there are problems in the current higher education laws and regulations, both universities and enterprises are not satisfied with the safeguard of higher education laws and regulations, as shown in Table 3. On the one hand, cultivating engineering talents through university-industry collaboration is still in the exploratory stage, so laws and regulations are incomplete. On the other hand, the law is based on the consideration of the national situation, so there are too many terms with a principled nature.

Table 3. Problems Existing in Relevant laws and Regulations

\begin{tabular}{|c|c|c|}
\hline Circumstances & Universities & Enterprises \\
\hline No problem & $0.0 \%$ & $0.0 \%$ \\
\hline Imperfect contents & $73.3 \%$ & $90.0 \%$ \\
\hline Poor operability & $46.7 \%$ & $30.0 \%$ \\
\hline $\begin{array}{c}\text { Inadequacy of } \\
\text { compulsion }\end{array}$ & $63.3 \%$ & $75.0 \%$ \\
\hline
\end{tabular}

The survey results on whether local governments have enacted regulations governing university-industry collaboration are also not satisfactory. The percentage of choosing "yes" in universities and enterprises are $36.2 \%$ and $35.0 \%$ respectively, which are relatively low.

Table 4. Whether the local government formulates the university-industry collaboration regulations

\begin{tabular}{|c|c|c|}
\hline Circumstances & Universities & Enterprises \\
\hline Yes & $36.2 \%$ & $35.0 \%$ \\
\hline No & $54.5 \%$ & $60.0 \%$ \\
\hline
\end{tabular}

\subsubsection{Current situation of mechanisms on university-industry collaboration}

In terms of the management mechanism, only $47.5 \%$ of government-level university-industry collaboration management institutions have been established. In the survey of problems existing in university-industry collaboration management, the data of universities and enterprises point to "multiple management departments and high coordination cost", accounting for $51.2 \%$ and $55.0 \%$ respectively. The more administrative departments, the greater the possibility of overlapping rights, leading to problems in the coordination of various departments. Almost all universities have set up institutions for university-industry collaboration, but only $25 \%$ of enterprises have set up institutions for university-industry collaboration. On the one hand, enterprises may feel no need to set up institutions. On the other hand, enterprises have not paid enough attention to university-industry collaboration. In terms of certification and evaluation mechanism, 64.7\% of universities and $60.0 \%$ of enterprises choose "no" when investigating whether enterprises have governmentrecognized qualifications for university-industry collaboration. Universities can only judge whether enterprises have the ability of university-industry collaboration according to their own experience, which increases the uncertainty of university-industry collaboration. In terms of tracking inspection and evaluation, universities still far outperform enterprises, as shown in Table 5 .

Table 5. Tracking inspection and evaluation circumstances

\begin{tabular}{|l|c|c|}
\hline Circumstances & Universities & Enterprises \\
\hline $\begin{array}{l}\text { The implementation of } \\
\text { university-industry } \\
\text { collaboration is } \\
\text { inspected }\end{array}$ & $84.6 \%$ & $45.0 \%$ \\
\hline $\begin{array}{l}\text { The results of } \\
\text { university-industry } \\
\text { collaboration are } \\
\text { evaluated }\end{array}$ & $86.3 \%$ & $55.0 \%$ \\
\hline
\end{tabular}

In terms of the interest-driven balance mechanism, when asked whether local governments have formulated financial investment policies related to university-industry collaboration, $52.4 \%$ of universities and $55.0 \%$ of enterprises choose "no". Therefore, there is no systematic policy system to support the development of universityindustry collaboration, and balance of interests and difficulties in university-industry collaboration require the government to strengthen coordination.

\subsubsection{Current situation of systems on university- industry collaboration}

All the universities under the survey have formulated specific management measures for university-industry collaboration, but only $19.2 \%$ of enterprises have done so. Institutional arrangements are needed for students to 
practice, enterprise employees to take part-time jobs in universities, and teachers to take part-time jobs in enterprises. The lack of institutional arrangements has adverse effects on university-industry collaboration. In addition, less than half of the enterprises enjoy preferential policies in the process of university-industry collaboration. Preferential policies for university-industry collaboration have not formed institutional arrangements, and enterprises' enthusiasm for participation has not been stimulated.

\section{COUNTERMEASURES AND SUGGESTIONS}

\subsection{The Government Improves Institutions, Policies and Regulations}

\subsubsection{Improve the safeguard mechanisms related to laws and regulations}

The government formulate laws and regulations on university-industry collaboration to clarify the proportion and limitation of capital investment, management and talents cultivation mode, responsibilities and rights of relevant departments, obligations and mutual relations among universities, students and enterprises. Moreover, the implementation measures for university-industry collaboration formulated by local governments are normative rules for managing university-industry collaboration in the certain region. It is not only an important part of higher education policies and regulations, but also a necessary supplement to higher education policies and regulations.

\subsubsection{Establish complete institutions for university-industry collaboration}

Establishing "University-industry Collaboration Decisionmaking Committee" is important, which is used to determine the cooperation plan, formulate relevant policies, and supervise the progress of the cooperation parties. Meanwhile, the government can establish the "Universityindustry Collaboration Executive Committee". Through negotiations, seminars, conferences and other forms, committees determine cooperation projects with universities and enterprises to achieve win-win development.

\subsubsection{Perfect the security for funds}

Britain, the United States, Germany, Australia and other countries have formulated policies to support universityindustry collaboration funds. For example, the Higher
Education Act of the United States clearly provides funds for university-industry collaboration, and it lists relevant funding contents separately [11].

In view of the shortage of funds in university-industry collaboration, the following measures can be adopted. First, the funds for higher education should be included in the financial budgets of the local government. Meanwhile, it is necessary to provide a relaxed environment for social capital investment and increase the non-financial investment of higher education funds. Third, supporting the establishment of various funds for university-industry collaboration can expand funding sources.

\subsection{Establishing the Self-safeguard Organization and Improving the Teaching Quality are Necessary for Universities}

\subsubsection{Establish specialized institutions for university-industry collaboration}

In order to solve problems in the process of universityindustry collaboration, universities should establish specialized institutions with clear division of labor. First, establishing "Leading Group on University-industry Collaboration" to guide matters related to universityindustry collaboration is necessary. Meanwhile, universities should establish "University-industry Collaboration External Affairs Office", which is specially used to find target enterprises, coordinate the implementation of projects, and track the results of projects. Also, the establishment of "University-industry Collaboration Executive Office" is of great value for the formation of project operation team and careful implementation of projects. Besides, universities should establish "UniversityIndustry Collaboration Communication Committee" whose function is to strengthen the communication between universities and stakeholders.

\subsubsection{Construct the quality assurance system for professional talents}

Universities should build a curriculum system on the basis of cultivating students' ability to solve practical problems with professional knowledge. The curriculum is oriented to increase students' employment opportunities and improve their knowledge structure. It is of great significance to construct a teaching system which is based on theory, carried by practice and combined with practice. Universities can also evaluate students' abilities according to their performance in the enterprise in addition to examinations and papers.

In order to solve the problem of teachers' lack of experience in guiding students' practice, universities and enterprises can cooperate closely to create a double-qualified teaching team [12]. First, universities improve the system of holding a 
temporary position in enterprises, and they create opportunities for teachers to practice in enterprises. Meanwhile, setting up "double-qualified" allowance can encourage teachers to improve their practical teaching ability. Third, introducing part-time teachers from enterprises is necessary.

\subsection{Enterprises Establish Relevant Institutions and Systems}

\subsubsection{Establish specialized institutions for university-industry collaboration}

Enterprises assume certain social responsibilities, so they should take the initiative to accept students' intern and teachers' practice. Moreover, it is important to build corresponding management institutions. Students' intern and teachers' practice should be provided with convenience, and guidance personnels should be properly arranged to ensure the safety of students and teachers during practice. Specialized institutions should be responsible for determining training objectives, providing training conditions, communication with universities.

\subsubsection{Improve relevant systems}

Institutionalization is the important safeguard for establishing long-term mechanism of university-industry collaboration. Enterprises should establish a marketoriented enterprise system and a sound talents cultivation system. Employees must be encouraged to participate in vocational training to improve their ability to adapt to the market. In addition, enterprises should formulate universityindustry collaboration management measures in student internship, teacher practice and other aspects, which should also clearly illustrate the conditions, procedures and assessment for employees to take part-time jobs in universities.

\section{CONCLUSION}

At present, the laws and regulations related to universityindustry collaboration have problems of imperfect contents and weak operability. Moreover, the lack of complete institutions managing university-industry collaboration is an important reason for the poor implementation effect. The certification and evaluation mechanism for use of funds, process and effect of collaboration also needs to be improved. The tax break or reward measures for enterprises to participate in university-industry collaboration are not clear, which makes collaboration less attractive to enterprises. There is still no sound system to guarantee and plan the collaboration, so that the great value of universityindustry collaboration has not been exploited fully.
Based on the results of theoretical research and empirical analysis, countermeasures and suggestions to the government, universities and enterprises are proposed. First, improving institutions, policies and regulations are necessary for the government. Universities should not only establish the self-safeguard organization, but also construct the quality assurance system for professional talents. Meanwhile, enterprises need to establish relevant institutions and systems.

\section{ACKNOWLEDGMENT}

Sponsored by Ministry of Education humanities and social sciences research project special task (18JDGC014), the theoretical and practical research project of national vocational education innovation and development jointly constructed by Ministry of Education and Shandong province (GD22), and the fundamental research funds for the central universities (HIT.HSS.HXJS202006).

\section{REFERENCES}

[1] E. Crawley, J. Malmqvist, S. Őstlund, et al. Rethinking Engineering Education: The CDIO Approach, New York: Springer, 2007, pp. 2-13. DOI: https://doi.org/10.1007/978-0-387-38290-6

[2] L. Tan, "Study on the mode and mechanism of university-industry cooperation in training engineering talents," Education and Career,vol.30, 2013, pp.14-17. DOI: https://doi.org/10.13615/j.cnki.10043985.2013.30.067 (In Chinese)

[3] Z. Sun and Y. Zhang, "Thoughts on perfecting the practice mode of engineering talents training in China," Innovation and Entrepreneurship Education,vol.6, 2014, pp.39-41. (In Chinese)

[4] S. Ankrah and O. Al-Tabbaa, "Universities-industry collaboration: A systematic review," Scandinavian Journal of Management, vol. 31, 2015,pp. 387-408. DOI: https://doi.org/ 10.1016/j.scaman.2015.02.003

[5] R. Derakhshan, M. Mancini, and G. Fernandes, "Evolution of governance in a collaborative universityindustry program," Project Management Journal, vol. 51, 2020, pp.489-504. DOI: https://doi.org/10.1177/8756972820911245

[6] G. Fernandes, S. Leite, M. Araujo, A.C. Simoes, "Organizational enablers to the governance of collaborative university-industry R\&D programs," IEEE International Conference on Engineering, Technology and Innovation.England,vol.1, pp.1-9,June 2020 DOI: https://doi.org/10.1109/ICE/ITMC49519.2020.9198401 
[7] J. Bruneel, P. D’Este, A, Salter, “Investigating the factors that diminish the barriers to university-industry collaboration," Research Policy, vol.39, 2010, pp.858868. DOI: https://doi.org/10.1016/j.respol.2010.03.006.

[8] B. Hou, H. Jin and S. Xing, "Efficiency of university-industry collaboration and its determinants: evidence from Chinese leading universities." Industry \& Innovation, vol.28, 2021,pp. 456-85. DOI: https://doi.org/10.1080/13662716.2019.1706455.

[9] D. Su, D. Zhou, C. Liu, and L. Kong, "Governmentdriven university-industry linkages in an emerging country: The case of China." Journal of Science \& Technology Policy Management, vol. 6, 2015,pp.263282. DOI: https://doi.org/10.1108/JSTPM-02-20150008 .
[10] G. Harman, "University-industry research partnerships in Australia: extent, benefits and risks," Higher Education Research \& Development, vol.20, 2001, pp.245-264. DOI: https://doi.org/10.1080/07294360120108340

[11] M. Franco, H. Haase, "University-industry cooperation: Researchers' motivations and interaction channels," Journal of Engineering \& Technology Management, vol.36, 2015, pp.285-302 DOI: https://doi.org/pp.285-302. 10.1016/j.jengtecman.2015.05.002

[12] C. Zuo, The Current Situation, Problems and Countermeasures of the Application of Double Qualified Teachers' Education Technology, New York: Springer, 2019, pp. 1114-1121. DOI:

https://doi.org/doi:10.1007/978-3-030-15740-1_142 